\title{
Jernmangelanemi - tolking av biokjemiske og hematologiske funn
}

\begin{abstract}
BAKGRUNN Jernmangel og jernmangelanemi er hyppige problemstillinger i både primærog spesialisthelsetjenesten. Det er viktig å påvise jernmangel og utrede årsaksforhold, ettersom mangel kan være sekundært til alvorlig sykdom. Diagnosen jernmangel er i stor grad basert på biokjemiske og hematologiske laboratoriefunn, men det er ingen standardisering eller konsensus om tolkingen av slike funn.
\end{abstract}

KUNNSKAPSGRUNNLAG Vi har, ut fra våre kunnskaper om fagfeltet, foretatt et skjønnsmessig utvalg av artikler funnet etter et ikke-systematisk søk i databasen PubMed.

RESULTATER Ferritinmåling er den viktigste analysen ved utredning av jernmangel, men det er ingen konsensus om beslutningsgrense. I Norge er det i dag vanlig å forholde seg til et ferritinnivå på < 12-20 $\mu \mathrm{g} / \mathrm{l}$, men på dette nivået er sensitiviteten for påvisning av jernmangel svært lav. En rekke studier viser at hvis beslutningsgrensen økes til rundt $30 \mu \mathrm{g} / \mathrm{l}$, er sensitiviteten betydelig høyere, med bare liten reduksjon i spesifisitet.

FORTOLKNING Ved utredning av jernmangel som årsak til anemi bør beslutningsgrensen for påvisning av jernmangel være høyere enn den som brukes i dag. Ferritinnivået øker ved betennelsestilstander og bør i praksis ses i sammenheng med CRP-nivået. Nivået av transferrinreseptor i plasma øker ved jernmangel, uten å være påvirket av inflammasjon, og er derfor et godt supplement til ferritinmåling. Måling av jern, transferrin og transferrinmetning gir lite tillegginformasjon ved utredning av jernmangel.

Om lag $15 \%$ av norske kvinner i fertil alder lider av jernmangel (ferritinnivå $<12 \mu \mathrm{g} / \mathrm{l}$ ), og $3 \%$ har manifest jernmangelanemi (1). Hos norske barn er det påvist jernmangelanemi hos $10 \%$ av ettåringer (hemoglobinnivå $<11 \mathrm{~g} / 100 \mathrm{ml}$, ferritinnivå $<15 \mu \mathrm{g} / \mathrm{l}$ ) (2). Hos gravide er prevalensen av anemi på omkring $25 \%(\mathrm{Hb}<11 \mathrm{~g} / 100 \mathrm{ml})(3)$ i den vestlige verden, og over halvparten har jernmangel (4).

Jernmangel og jernmangelanemi er et uttrykk for underliggende sykdom - inntil det motsatte er bevist. Det kan være tilstander som gir nedsatt absorpsjon av jern eller økt tap i form av blødning. Det er viktig og nødvendig å påvise årsaksforholdene. I denne artikkelen beskrives nytte og begrensninger ved ulike biokjemiske og hematologiske analyser ved påvisning av jernmangel.

\section{Kunnskapsgrunnlag}

Artikkelen er basert på et ikke-systematisk søk i databasen PubMed. Det er gjort et skjønnsmessig utvalg av artikler ut fra forfatternes kompetanse og erfaring innen feltet.

\section{Kroppens jernomsetning}

Med et tradisjonelt kosthold får kroppen tilført ca. $10 \mathrm{mg}$ jern daglig. Av dette absorberes ca. $10 \%$ i duodenum, avhengig av det aktuelle innhold av jern i kroppen (fig 1) (5). Jern transporteres i blod bundet til det leverproduserte plasmaproteinet transferrin, hovedsakelig til beinmargen, der jernet brukes til produksjon av hemoglobin, og til ulike cel- lulære enzymsystemer, myoglobin og ulike jernlagre, bl.a. lever. I jernlagrene er jern bundet til ferritin. Ca. $70 \%$ av kroppens jerninnhold er i beinmarg og erytrocytter, mens rundt $20 \%$ finnes i jernlagrene. Det er ingen kjente reguleringsmekanismer for utskilling av jern gjennom tarm, urin og svette, og kroppens totale jerninnhold er derfor $i$ all hovedsak regulert via jernopptak i tarmen.

Figur 2 gir en oversikt over reguleringen av jernopptaket gjennom tarmen. Jern i kosten finnes enten som hemjern eller ikke-hemjern, og opptaket av hemjern er ikke regulert i samme grad som ikke-hemjernopptaket. Det totale jerninnhold i kroppen er den viktigste faktoren som påvirker jernopptaket. Mengden transferrinbundet jern registreres $i$ leveren via en transferrinreseptor, som igjen påvirker ekspresjonen av humant hemokromatoseprotein (HFE-protein) og andre proteiner. Disse igjen regulerer leverens produksjon av hepcidin, som påvirker aktiviteten til ferroportin. Det er vist at hepcidin har en nøkkelposisjon i reguleringen av jernstoffskiftet.

\section{Utredning av anemi}

Utredning av anemi generelt krever en grundig anamnese med vekt på tidsaspektet for utvikling av symptomer, kosthold, medikamentbruk (jerntilskudd, vitamintilskudd, antiflogistika), størrelse på menstruasjonsblødning, tidligere blødning i gastrointestinaltractus og etnisk bakgrunn. Ved mistanke om jernmangel er det spesielt viktig å være

\section{Tor-Arne Hagve}

tor.arne.hagve@ahus.no

Divisjon for diagnostikk og teknologi/TLMB

Akershus universitetssykehus

Institutt for klinisk medisin

Universitetet i Oslo

Kristin Lilleholt

Avdeling for medisinsk biokjemi

Sørlandet sykehus, Kristiansand

Marianne Svendsen

Avdeling for medisinsk biokjemi

Oslo universitetssykehus, Rikshospitalet

\section{HOVEDBUDSKAP}

Måling av ferritinnivå er den viktigste analysen ved utredning av jernmangel

Beslutningsgrensen for ferritinnivå bør $ø$ kes fra det i Norge tradisjonelle $12-20 \mu \mathrm{g} / \mathrm{l}$ til $30-40 \mu \mathrm{g} / \mathrm{l}$ for å bedre sensitiviteten for påvisning av jernmangel

Måling av jern, transferrin og transferrinmetning gir lite tilleggsinformasjon

Måling av transferrinreseptor er nyttig ved jernmangel med samtidig inflammasjon 
seg bevisst at for voksne personer uten blødning og med normal absorpsjon i tarmen blir behovet for jern dekket gjennom et variert kosthold.

Jern resirkuleres i kroppen slik at daglig opptak og tap er på omkring $1 \mathrm{mg}$. En blødning på $50 \mathrm{ml}$ innebærer et ekstratap på ca. $25 \mathrm{mg}$. Barn og ungdom i vekst, gravide og personer med ensidig kosthold eller lavt totalt energiinntak risikerer å utvikle jernmangel også uten at det foreligger blødning.

Inntaket av jern er relatert til det totale matinntaket. Et barn i vekst har bortimot samme behov for jern som en voksen mann, men spiser mindre og har betydelig større risiko for å få jernmangel enn voksne.

Utredningen for øvrig for å avdekke eventuell jernmangel som årsak til anemi er hovedsakelig basert på biokjemiske og hematologiske analyser.

\section{Biokjemiske analyser \\ Ferritinmålinger}

Plasma-ferritinnivået i er i utgangspunktet et godt mål på kroppens jernlagre, hvilket er godt dokumentert, ikke minst i den nå klassiske systematiske oversiktsartikkelen til Guyatt og medarbeidere (6). Her ble det ved gjennomgang av 55 studier, selektert fra $i$ alt 1179 relevante referanser, funnet at ferritinmåling har klart best diagnostisk treffsikkerhet for påvisning av jernmangel som årsak til anemi sammenliknet med andre hematologiske og biokjemiske analyser. I de aller fleste av de aktuelle studiene var jernmangel bekreftet ved jernfarging av beinmarg. ROC-analyse (receiver operating character-

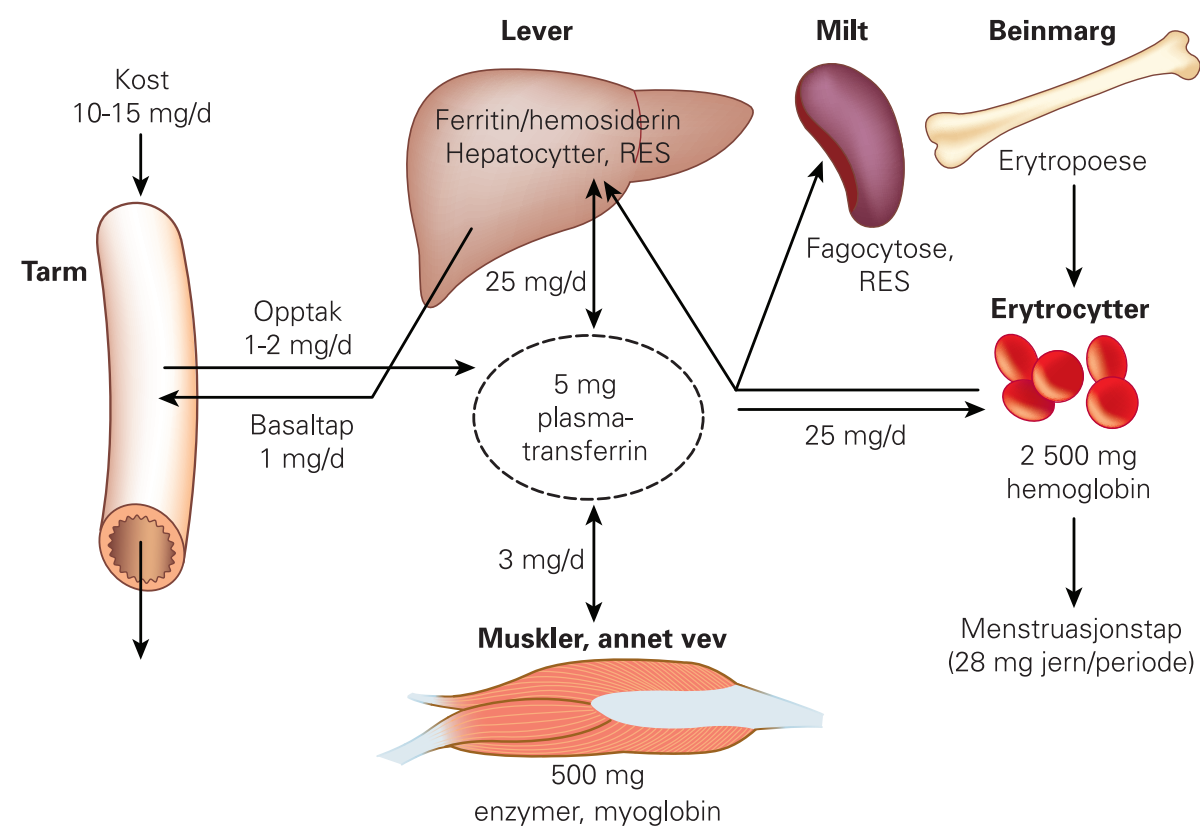

Figur 1 Oversikt over daglig jernomsetning i kroppen (5). Illustrasjon $\odot$ A. Langdalen

istic) viste at areal under kurven (AUC) for ferritin var så høyt som 0,95 . Til sammenlikning var AUC 0,74 og 0,76 for henholdsvis transferrinmetning og gjennomsnittlig cellevolum i de røde blodcellene (mean corpuscular volume, MCV).

Nytten av ferritinmålinger er imidlertid begrenset, både på grunn av lav sensitivitet og fordi nivået stiger ved aktiv prosess og ved akutt leversykdom.

Lavt ferritinnivå er patognomonisk for reduserte eller tomme jernlagre $(6,7)$. Beslutningsgrensen for ferritinnivå ved påvisning av jernmangel som årsak til anemi er vanligvis satt $\mathrm{i}$ området rundt nedre referansegrense, dvs. $15-25 \mu \mathrm{g} / \mathrm{l}$, avhengig av analysemetode (8). I dette området er imidlertid sensitiviteten for å påvise jernmangel lav. Det er $\mathrm{i}$ en rekke studier vist at ved å bruke en høyere beslutningsgrense, dvs. i området $30-45 \mu \mathrm{g} / \mathrm{l}$, stiger den positive prediksjonsverdien betydelig (9). Hos gravide med

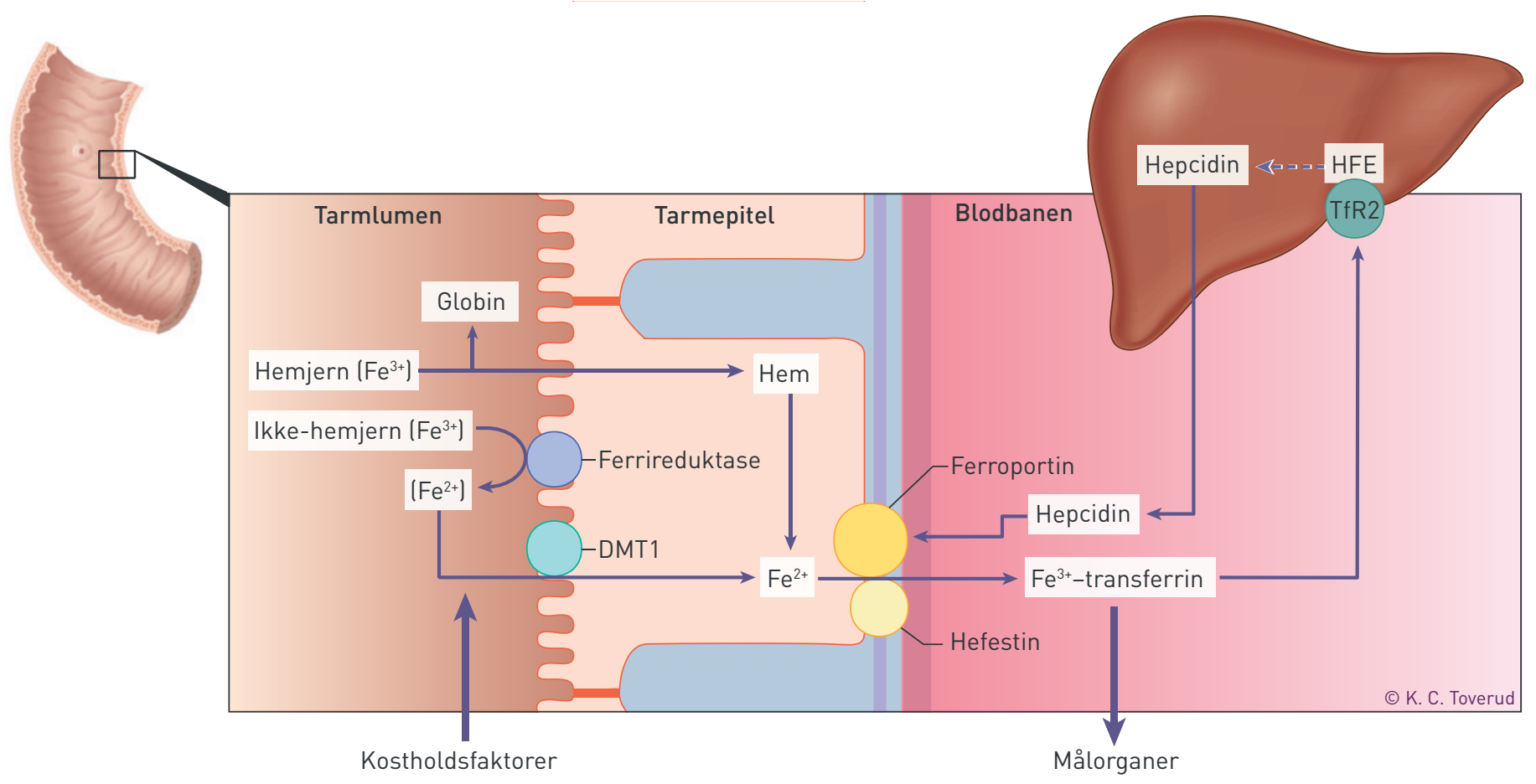

Figur 2 Regulering av opptak av jern i tarmen. Ikke-hemjern forekommer som treverdige hydroksider og må reduseres (av ferrireduktase) til toverdig jern på den luminale membransiden av enterocytten før transport inn via divalent metalltransporter 1 (DMT1). Kostfaktorer og tarmens pH påvirker ioniseringen, dels også jerntransporten gjennom membranen og dermed også det totale opptaket. Ved den basale membranen transporteres jernet ved hjelp av eksportproteinet ferroportin, reoksideres av hefestin og bindes til transferrin for videre transport 


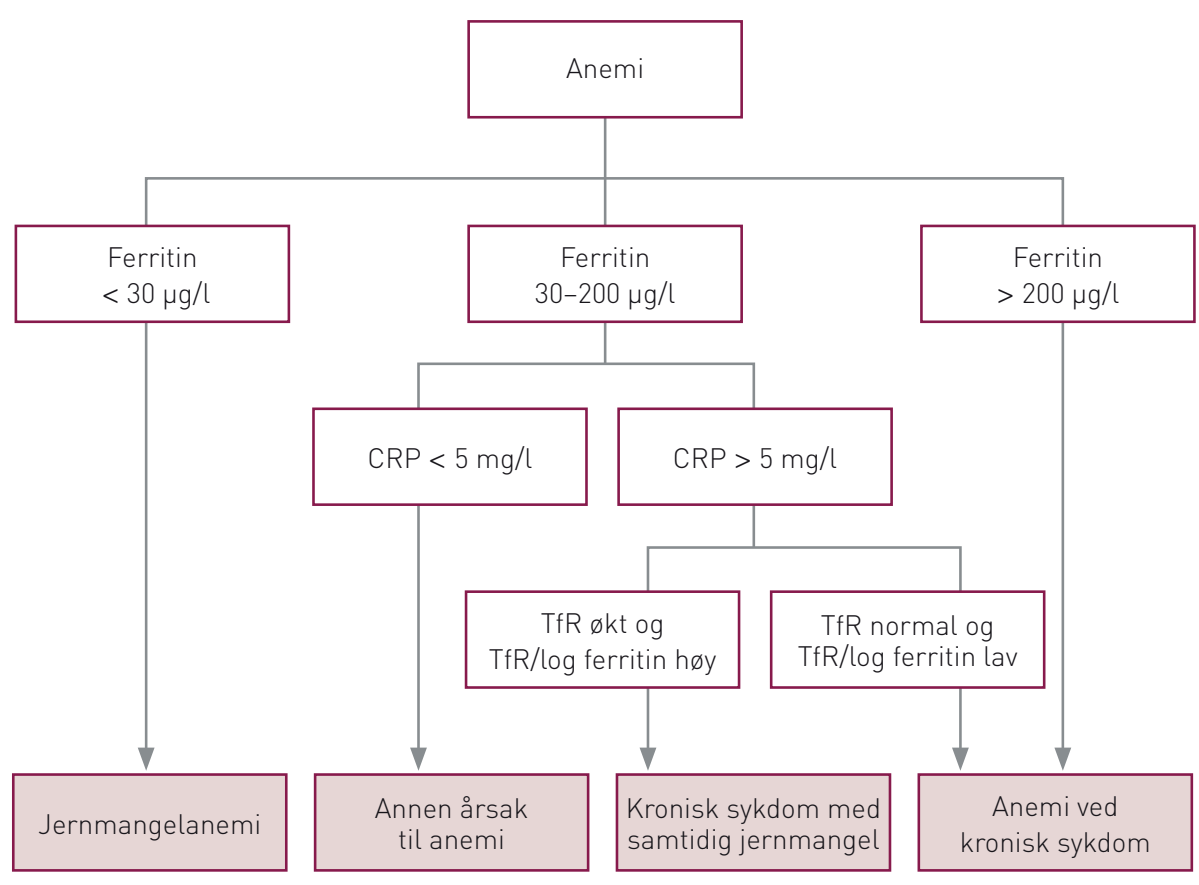

Figur 3 Forslag til rutine for utredning av jernmangelanemi

anemi i en populasjon med samtidig høy forekomst av akutt eller kronisk sykdom økte ferritinnivåets sensitivitet fra $37,5 \%$ ved en beslutningsgrense på $\leq 12 \mathrm{~g} / 1$ til $90 \%$ ved en beslutningsgrense på $\leq 30 \mu \mathrm{g} / \mathrm{l}$ (7). Det ble observert en mindre reduksjon i spesifisitet fra $93,7 \%$ til $85,1 \%$.

På samme måte konkluderte Guyatt og medarbeidere med at under $40 \mu \mathrm{g} / \mathrm{l}$ vil lavere ferritinnivå tilsi desto større sannsynlighet for jernmangel, og at verdier over $40 \mu \mathrm{g} / \mathrm{l} \mathrm{i}$ økende grad taler imot jernmangel (6). Hos friske gravide kan det imidlertid være vanskelig å bruke ferritinnivået til å diagnostisere jernmangelanemi i 2 . og 3 . trimester. I en skandinavisk studie ble det vist at $90 \%$ av kvinnene har et ferritinnivå på $<25 \mu \mathrm{g} / \mathrm{log}$ at $50 \%$ har et nivå på $<12 \mu \mathrm{g} / 1$ i svangerskapsuke 29-36 (10). Det antas at dette i stor grad skyldes en kombinasjon av fysiologisk hemodilusjon og det faktum at en stor andel av kroppens jern går med til økt erytopoese.

En økning av beslutningsgrensen for ferritin har kliniske konsekvenser, noe som er vist $i$ en studie fra USA. På to sykehus endret man den da tilfeldige oppfølgingen av ferritinmålinger med beslutningsgrense i størrelsesorden $20 \mu \mathrm{g} / 1$ til en ny rutine hvor det hos alle pasienter med anemi og MCV $<95 \mathrm{fl}$ ble rekvirert ferritinmåling. Alle pasienter med ferritinnivå $<45 \mu \mathrm{g} / 1$ ble endoskopert (11). Valget av beslutningsgrense var basert på tidligere publiserte data, som viste at pasienter med ferritinnivå $<45 \mu \mathrm{g} / \mathrm{l} \mathrm{og}$ anemi har høy sannsynlighet for jernmangel, med en sensitivitet på $85 \%$ og en spesifisitet på $92 \%$ (6). For ferritinnivåer i områdene $<45 \mu \mathrm{g} / \mathrm{l}, 46-100 \mu \mathrm{g} / \mathrm{l}$ og $>100 \mu \mathrm{g} / \mathrm{l}$ ble det funnet en sannsynlighetsratio for jernmangel på henholdsvis $11,0,5$ og 0,1 .
Etter innføring av de nye rutinene ble det utført ferritinmålinger hos et økt antall pasienter med anemi. Det ble også utført endoskopi hos flere, og det var patologiske funn i tarmen hos ca. $60 \%$ flere enn tidligere. Over halvparten av dem med jernmangelanemi av ukjent årsak har en eller annen form for gastrointestinal lesjon, og av disse er $10-15 \%$ maligne (12). Den vanligste årsaken til jernmangelanemi hos voksne i industrialiserte land er nettopp blodtap, ofte kronisk småblødning fra gastrointestinaltractus (13). Fallende ferritinnivå kan være første indikator på dette.

Ferritin er et akuttfaseprotein, og nivået stiger ved inflammasjon. Dette er et problem ved bruk av ferritinnivå som markør for kroppens jerninnhold, fordi ferritinnivået dermed kan være normalt eller forhøyet hos pasienter med jernmangel. Det er derfor foreslått å øke terskelverdien for å mistenke jernmangel som årsak til anemi fra $30-40 \mu \mathrm{g} / \mathrm{l}$ til 70-200 $\mu \mathrm{g} / 1$ når det foreligger tegn til aktiv prosess. CRP-måling kan være et hjelpemiddel til å vurdere tilstedeværelse av inflammasjon $(11,14)$.

\section{Transferrinreseptor}

Ferritinmålinger avspeiler kroppens lagerjern, mens løselig trasferrinreseptor (TfR) er et mål for tilgjengelighet av jern for erytropoese. TfR-mengden i cellemembranen gjenspeiler jernbehovet til den aktuelle celle. Når det er lite jern tilgjengelig, oppreguleres TfR-produksjonen. I blodbanen er det en løselig form for trasferrinreseptor som gjenspeiler den totale mengden membranbundet trasferrinreseptor i kroppen (15).

Ved utvikling av jernmangelanemi vil TfR-mengden øke tidlig i prosessen, som en konsekvens av at det er for lite jern tilgjengelig for normal erytropoese. Det er beskrevet tilfeller med målbar økning i TfR-nivået når jernlagrene er tomme - før utvikling av anemi (16). Tolking av TfR-målinger er også komplisert ved at transferrinreseptornivået øker ved økt erytropoese, slik som ved hemolyse, myelodysplasi (17), leukemi (18) og erytropoietinbehandling (19).

I motsetning til nivåene av ferritin, jern og transferrin påvirkes ikke TfR-nivået av en aktiv prosess. TfR-måling kan derfor være nyttig for å påvise jernmangel ved samtidig inflammasjon. Ferritinnivå og transferrinmetning er da vanskelig å tolke, selv med kjennskap til CRP-nivået, mens TfR-nivået vil være økt upåvirket av inflammasjonsaktiviteten.

\section{Målinger av både ferritin og TfR}

Ved jernmangel er ferritinnivået lavt (små lagre) og TfR-nivået økt (lite jern tilgjengelig for erytropoese på cellulært nivå). Kombinasjoner av disse to situasjonene er vist å være et godt mål på graden av jernmangel og er bedre enn målinger av ferritin og TfR alene $(8,16,20)$. Det er vist at ratioen mellom TfR og log ferritin - sammen med CRPmålinger - kan skille mellom jernmangelanemi (høy ratio, lav CRP-verdi), anemi forårsaket av kronisk sykdom (lav ratio, høy CRP-verdi) og en kombinasjon av disse to tilstandene (høy ratio, høy CRP-verdi) (21).

For verdier i gråsonen for aktuelle grenseverdier for ratio er det anbefalt jernfarging av beinmargsaspirat. Beslutningsgrense for ratio $\mathrm{TfR} / \log$ ferritin vil avhenge av analytisk metode for ferritin og TfR. Rasjonalet for å bruke logaritmen for ferritin er at den delen av økningen som er forårsaket av aktiv prosess blir redusert.

\section{Jern, transferrin og transferrinmetning}

Det klassiske bildet ved jernmangel er lavt jernnivå, høyt transferrinnivå og lav transferrinmetning i plasma.

Den lille mengde jern som finnes i plasma, avspeiler først og fremst balansen mellom produksjon og destruksjon av erytrocytter. Jern resirkuleres i kroppen, og omsetningen i plasma er høy. Interindividuell og intraindividuell variasjon for jern i plasma er stor, også i løpet av ett døgn (22), noe som gjør jernmåling alene ubrukelig ved utredning av jernmangel. Jernnivået i plasma må alltid ses i sammenheng med transferrinnivået, uttrykt som transferrinmetning $(100 \times($ jern/transferrin $\times 25,1)$ ).

De fleste laboratorier rapporterer automatisk transferrinmetning når det er rekvirert måling av jern og transferrin i plasma. Men både jern og transferrin er påvirket av aktive prosesser, og nivåene faller ved inflammasjon, noe som kan gjøre tolkingen vanskelig. Store studier viser at transferrinmetning er mindre sensitivt og mindre spesifikt enn måling av ferritin og transferrinreseptor ved påvisning av jernmangel og at det ikke gir 
noen tilleggsgevinst $(6,7)$. Tolking av transferrinmetning kompliseres av at østrogener, f.eks. ved p-pillebruk og graviditet, gir stigning i transferrinnivået og dermed reduksjon i transferrinmetningen.

\section{Hematologiske analyser}

\section{$\mathrm{MCV}, \mathrm{MCH}$ og RDW}

Klassisk jernmangel er i lærebøker ofte definert som mikrocytær og hypokrom. Det er imidlertid ingen konsensus for beslutningsgrense for $\mathrm{MCV}$ og $\mathrm{MCH}$ (mean corpuscular hemoglobin, gjennomsnittsinnholdet av hemoglobin per erytrocytt) ved diagnostikk av jernmangel, og de fleste aktuelle studier konkluderer med at MCV og MCH har dårligere prediksjonsverdi for anemidiagnosen enn biokjemiske variabler, særlig ferritin $(6,7)$.

Den vanligst brukte terskelverdi for MCV ved diagnose av jernmangel er i størrelsesorden $<82 \mathrm{fl}$, men sensitiviteten på dette nivået er lav. Hvis man ønsker å bruke MCV for å utelukke jernmangelanemi, bør grensen settes så høyt som < $95 \mathrm{fl}$ (sensitivitet 97,6\%) (6). Det hevdes også at MCV og enda mer MCV-MCH-ratioen er nyttig for å skille mellom jernmangel og talassemi (23). Bakgrunnen er at MCV er lavere ved talassemi enn ved jernmangel, mens $\mathrm{MCH}$ er på samme nivå ved de to tilstandene.

De fleste hematologiinstrumenter måler MCV omkring 6-10\% for høyt ved oppbevaring av prøven i romtemperatur ett døgn før analyse (egne upubliserte data). Dette gjør MCV mindre anvendelig ved lang transporttid til laboratoriet. $\mathrm{MCH}$ er derimot en stabil variabel, og det er god samvariasjon mellom MCV og MCH.

Røde blodcellers distribusjonsbredde (red cell distribution width, RDW) gir et mål på variasjonen i erytrocyttvolum (anisocytose). Ved jernmangel er RDW-verdien økt. RDW er av Guyatt og medarbeidere karakterisert som den minst nyttige analysen, med en AUC på 0,62 (6). Økende RDW-verdier med samtidig økende MCV indikerer vellykket substitusjonsbehandling ved jernmangel.

\section{Hemoglobininnhold i reticulocytter}

Erytrocyttanalyser gir et bilde av erytrocyttproduksjonen i løpet av de siste 120 dager. Ved utvikling av jernmangel vil det derfor ta tid før MCV og $\mathrm{MCH}$ påvirkes. Retikulocytter, derimot, er i sirkulasjonen i bare 1-2 dager og gir et øyeblikksbilde av erytropoetisk aktivitet. Hemoglobininnholdet i retikulocyttene, dvs. $\mathrm{CHr}$, RetHe, $\mathrm{MCHr}$, er antatt å gi et bilde av tilgjengelighet av jern for hemoglobinproduksjon i beinmargen i nåtid. Dette er ulike navn gitt til samme analysevariabel av tre ulike instrumentprodusenter (24). Det er i en studie vist liten forskjell i nivå og god samvariasjon mellom $\mathrm{CHr}$ og RetHe (24). Ved sammenliknende ringtester i Norge er det imidlertid vist at nivået varierer noe mellom de ulike metoder og instrumenter.

Moderne helautomatiske hematologi- instrumenter kan også kvantitere størrelsen på populasjonen av hypokrome celler (\%HYPO), definert som $\mathrm{CH}<28 \mathrm{~g} / 100 \mathrm{ml}$. \%HYPO er et mer langsiktig mål på jerntilgjengelighet enn $\mathrm{CHr}$. Begge er spesielt studert ved vurdering av jernbehov i forbindelse med erytropoietinbehandling av anemi ved nyresvikt og ved anemi ved kronisk sykdom og jernmangel hos barn (25-28). Da \%HYPO er avhengig av erytrocyttenes volum, vil den kunne bli falskt forhøyet ved oppbevaring i romtemperatur i mer enn to timer før analyse.

\section{Konklusjon}

Figur 3 viser hovedlinjene i utredning av anemi for å avdekke jernmangel som årsak. Modellen er basert på en høyere terskelverdi for ferritin $(<30 \mu \mathrm{g} / \mathrm{l})$ enn det som brukes mest i dag. For et ferritinnivå på 30-200 $\mu \mathrm{g} / \mathrm{l}$ er TfR-måling - og enda bedre TfR-log ferritin-ratio - det beste alternativet for å skille mellom anemi ved aktiv prosess og samtidig jernmangel.

Det begynner også å bli aksept for at $\mathrm{CHr} /$ $\mathrm{RetHe} / \mathrm{MCHr}$ har en plass i utredninger for å skille mellom ulike former for anemi relatert til jernstoffskiftet, men ved bruk av publiserte beslutningsgrenser kan det være et problem at forskjellige måleinstrumenter er ulikt kalibrert. \%HYPO brukes i forbindelse med erytropoietinbehandling og nyresvikt. Andre biokjemiske og hematologiske analyser gir lite diagnostisk informasjon i tillegg til ferritin- og TfR-målinger.

\section{Tor-Arne Hagve (f. 1953)}

er overlege i medisinsk biokjemi ved Tverrfaglig laboratoriemedisin og medisinsk biokjemi,

Akershus universitetssykehus, og professor II ved Institutt for klinisk medisin, Universitetet i Oslo. Forfatter har fylt ut ICMJE-skjemaet og oppgir ingen interessekonflikter.

\section{Kristin Lilleholt (f. 1966)}

er overlege i medisinsk biokjemi ved Avdeling for medisinsk biokjemi, Sørlandet sykehus, Kristiansand

Forfatter har fylt ut ICMJE-skjemaet og oppgir ingen interessekonflikter.

\section{Marianne Svendsen (f. 1953)}

er bioingeniør og enhetsleder ved Laboratoriet barneklinikken, Avdeling for medisinsk biokjemi, Oslo universitetssykehus, Rikshospitalet. Forfatter har fylt ut ICMJE-skjemaet og oppgir ingen interessekonflikter.

\section{Litteratur}

1. Borch-lohnsen B, Sandstad B, Asberg A. Iron status among 3005 women aged $20-55$ years in Central Norway: the Nord-Trøndelag Health Study (the HUNT study). Scand J Clin Lab Invest 2005; 65 45-54.

2. Hay G, Sandstad B, Whitelaw A et al. Iron status in a group of Norwegian children aged 6-24 months. Acta Paediatr 2004; 93: 592-8
. Bruno de Benoist B, McLean E, Egli I et al. red Worldwide prevalence of anaemia 1993-2005 WHO global database on anaemia. Genève: WHO 2008.

4. Iron deficiency anaemia: assessment, prevention, and control. A guide for programme managers. Genève: WHO, 2001

5. Borch-lohnsen B, Hagve T-A, Hauge A et al. Regulering av jernbalansen. Tidsskr Nor Legeforen 2009; 129: 858-62.

6. Guyatt GH, Oxman AD, Ali M et al. Laboratory diagnosis of iron-deficiency anemia: an overview. J Gen Intern Med 1992; 7: 145-53.

7. van den Broek NR, Letsky EA, White SA et al. Iron status in pregnant women: which measurements are valid? Br J Haematol 1998; 103: 817-24.

8. Cook JD. Iron deficiency anemia. Baillieres Clin Haematol 1994; 7: 787-804.

9. Mast $A E$, Blinder MA, Gronowski $A M$ et al. Clinical utility of the soluble transferrin receptor and com parison with serum ferritin in several populations. Clin Chem 1998; 44: 45-51.

10. Rasmussen S, Bergsjø P. Jacobsen $G$ et al. Haemoglobin and serum ferritin in pregnancy correlation with smoking and body mass index. J Obstet Gynecol Reprod Biol 2005; 123: 27-34

11. Ioannou GN, Spector J, Scott K et al. Prospective evaluation of a clinical guideline for the diagnosis and management of iron deficiency anemia. Am J Med 2002; 113: $281-7$

12. Rockey DC, Cello JP. Evaluation of the gastrointestinal tract in patients with iron-deficiency anemia. N Engl J Med 1993; 329: 1691-5.

13. Cook JD, Skikne BS. Iron deficiency: definition and diagnosis. J Intern Med 1989; 226: 349-55.

14. Means RT jr., Allen J, Sears DA et al. Serum soluble transferrin receptor and the prediction of marrow aspirate iron results in a heterogeneous group of patients. Clin Lab Haematol 1999; 21: 161-7.

15. R'zik S, Beguin Y. Serum soluble transferrin receptor concentration is an accurate estimate of the mass of tissue receptors. Exp Hematol 2001, 29: 677-85.

16. Skikne BS, Flowers CH, Cook JD. Serum transfer rin receptor: a quantitative measure of tissue iron deficiency. Blood 1990; 75: 1870-6.

17. Cook JD, Skikne BS, Baynes RD. Serum transferrin receptor. Annu Rev Med 1993; 44: 63-74.

18. Klemow D, Einsphar D, Brown TA et al. Serum transferrin receptor measurements in hematologic malignancies. Am J Hematol 1990; 34: 193-8.

19. Skikne BS, Cook JD. Effect of enhanced erythropoiesis on iron absorption. J Lab Clin Med 1992 120: $746-51$

20. Punnonen K, Irjala K, Rajamäki A. Serum transferrin receptor and its ratio to serum ferritin in the diagnosis of iron deficiency. Blood 1997; 89 1052-7.

21. Skikne BS. Serum transferrin receptor. Am J Hematol 2008; 83: 872-5

22. Tietz NW, Rinker AD, Morrison SR. When is a serum iron really a serum iron? The status of serum iron measurements. Clin Chem 1994 40: $546-51$

23. d'Onofrio G, Zini G, Ricerca BM et al. Automated measurement of red blood cell microcytosis and hypochromia in iron deficiency and beta-thalasse mia trait. Arch Pathol Lab Med 1992; 116: 84-9.

24. Thomas L. Franck S, Messinger $M$ et al. Reticulocyte hemoglobin measurement-comparison of two methods in the diagnosis of iron-restricted erythropoiesis. Clin Chem Lab Med 2005; 43: 1193-202.

25. Macdougall IC, Cavill I, Hulme B et al. Detection of functional iron deficiency during erythropoietin treatment: a new approach. BMJ 1992; 304: 225-6.

26. Mittman N, Sreedhara R, Mushnick R et al. Reticulocyte hemoglobin content predicts functional iron deficiency in hemodialysis patients receiving rHuEPO. Am J Kidney Dis 1997: 30: 912-22.

27. Ullrich $C$, Wu A, Armsby $C$ et al. Screening healthy infants for iron deficiency using reticulocyte hemoglobin content. JAMA 2005; 294: 924-30.

28. Walters GO, Miller FM, Worwood M. Serum ferritin concentration and iron stores in normal subjects. J Clin Pathol 1973; 26: 770-2. 